\title{
NEW ROAD INFRASTRUCTURE DEVELOPMENT AND LOCAL COMMUNITY WELFARE: EVIDENCE FROM TOLLER DOOR IN MALANG OF INDONESIA
}

\author{
Linda Seprillina, Ermita Yusida, Bagus Shandy Narmaditya \& Yessica.Y.C Chung \\ Universitas Negeri Malang, Indonesia and National Pingtung University, Taiwan \\ linda.Seprillina.fe@um.ac.id, ermita.yusida.fe@um.ac.id, bagus.shandv.fe@um.ac.id, vessicachung@mail.npust.edu.tw
}

\begin{abstract}
The purpose of this study aims to explore the impact caused by the construction of toll roads from the four access gates built by the government and community economies in the area. Using the quantitative description method and the Logit test with a sample of 200 respondents from the four Malang-Pandaan exit gate locations, the findings indicate that the impact of this infrastructure has been seen from changes in the level of income and expenditure that increased after the construction of the exit toll. However, an enhance in the expenditure or consumption level of local communities has a less significant impact, especially in terms of consumption of basic household needs and asset ownership. This implicates that infrastructure development built by the government has not given maximum results as expected by local communities in terms of improving the welfare of surrounding communities.
\end{abstract}

Keywords: Infrastructure Development, Toller Door, Local Community Welfare, Economic Development

\section{PEMBANGUNAN INFRASTRUKTUR JALAN BARU DAN KESEJAHTERAAN MASYARAKAT LOKAL: BUKTI DARI PINTU TOL DI MALANG INDONESIA}

\begin{abstract}
Abstrak: Tujuan penelitian ini bertujuan untuk mengetahui dampak yang ditimbulkan oleh pembangunan jalan tol dari empat pintu akses yang dibangun oleh pemerintah dan perekonomian masyarakat di daerah tersebut. Dengan menggunakan metode deskripsi kuantitatif dan uji Logit dengan sampel sebanyak 200 responden dari empat lokasi pintu keluar Malang-Pandaan, didapatkan hasil bahwa dampak dari infrastruktur ini terlihat dari perubahan tingkat pendapatan dan pengeluaran yang meningkat setelah adanya peningkatan pembangunan pintu keluar tol. Namun, peningkatan belanja atau konsumsi masyarakat lokal berdampak kurang signifikan, terutama dalam hal konsumsi kebutuhan pokok rumah tangga dan kepemilikan aset. Hal ini berimplikasi pada pembangunan infrastruktur yang dibangun pemerintah belum memberikan hasil yang maksimal seperti yang diharapkan masyarakat setempat dalam meningkatkan kesejahteraan masyarakat sekitar.
\end{abstract}

Kata kunci: Pembangunan Infrastruktur, Pintu Tol, Kesejahteraan Masyarakat Lokal, Pembangunan Ekonomi

\section{INTRODUCTION}

The state dramatically needs economic development to improve the people's standard of living and welfare (Seprillina et al., 2019; Sutikno \& Wahyudi, 2017). In general, the goal of a country is to achieve economic stability and economic growth, which is reflected in an increase in Gross Domestic Product (GDP) and diminish unemployment rate (Rahmawati et al., 2020; Sahnoun \& Abdennadher, 2019). To accomplish these goals, the government needs a variety of supporting factors, one of which is the existence of infrastructure (Bom \& Ligthart, 2014). Infrastructure development needs will rise along with an enhance in economic activity (Chandra \& Thompson, 2000). One result of development changes in a nation is infrastructure conditions (Wulandari et al., 2019). 
In addition to infrastructure variables, institutional and governance variables also have a positive effect on the economy in a nation (Kyriacou, 2016). This implies that a country with a good institutional and governance system can manage infrastructure development better. Therefore, it can have a more positive effect on a country's economy. Indeed, the prior study by Esfahani \& Ramírez (2003) using macroeconomic data noted the significant impact of infrastructure development on the economy. The detail of the relationship between economic growth and road investment is provided in Table 1.

Table 1. Comparison of 2014-2018 Economic Growth and Road Investment

\begin{tabular}{ccc}
\hline Year & GDP & Road Investment \\
\hline 2014 & 6.06 & 537,581 \\
2015 & 6.08 & 573,233 \\
2016 & 6.12 & 667,335 \\
2017 & 6.36 & 724,327 \\
2018 & 6.50 & 888,972 \\
\hline
\end{tabular}

Source: Data Processed from World Bank (The World Bank, 2019)

Table 1 shows that economic growth and road investment have increased positively. With a positive influence between the development of road investment (road infrastructure) and economical implies on the enhancing of economic activity. Considering this fact, infrastructure is the main foundation in promoting sustainable economic growth. Similarly, the previous study by Annala et al. (2008) documented that public infrastructure development in Japan, in particular, could boost the economy. Wulandari et al. (2019) also noted that the development of basic infrastructure in the Southern road of East Java in Indonesia has successfully enhanced community welfare.

The transportation infrastructure can also be viewed from the aspect of toll road facilities are needed to connect all economic activities and achieve equal distribution. Specifically, building a toll road network is one of the prerequisites for the development of economic activities to connect remote areas and the mainstream of the economy area. Furthermore, the construction of road infrastructure such as the construction of toll roads in Indonesia, aims to reduce the level of congestion that has been happening in various areas that are the main axis for carrying out economic activities. Therefore, the impact is that it can improve people's lives in terms of income and time efficiency.

For this reason, an effort to increase the level of income and make time efficient is to improve infrastructure that will drive the community welfare. Ye et al. (2019) argued that a favourable urban environment is the most crucial aspect of city competitiveness and urban development goals directly related to the public interest. It also involves the quality of life of the population and the sustainable development of urban society and its economy. To create an urban environment that has the competitiveness and supports sustainable development, the Indonesian government has been carrying out intensive infrastructure development.

Perkins et al. (2005) explained three functions and causality between infrastructure and economic growth. First is the relationship between infrastructure and economic growth going in both directions. The meaning is that if infrastructure development is inadequate, the impact will be to drive congestion problems. This problem will be an opportunity to reduce the country's economic growth because people are reluctant to enjoy or use inadequate infrastructure development. The second is that infrastructure development to improve the economy must 
gradually develop, and government policies must be aligned with effective and efficient plans for building infrastructure. The third is the need for infrastructure development and maintenance at any time will be needed; this relates to support any economic activities carried out by the community by calculating the appropriate cost-benefit analysis.

Since the importance of infrastructure development for an economy in a nation, the study on this issue is also rising. Several antecedents studies have linked infrastructure development and economic growth in various countries (Cigu et al., 2018; $\mathrm{Ng}$ et al., 2019; 2015). While in the Indonesian context, Wulandari et al. (2019) focused on the impact of Southern road establishment of East Java and community development. Another study by Nugraha et al. (2020) concerned infrastructure development and inequality in Indonesia. However, there is little attention from scholars that focuses on the impact of infrastructure development, particularly the establishment of road toll and community welfare.

This study proposes two main contributions. First, this study contributes to the existing literature on infrastructure development and its impacts on the economy. This study adds insights from the community perspectives toward these changes. Second, the research in Indonesia is unique due the government has concerned about infrastructure development. The World Bank (2019) remarked that inaccurate infrastructure investment would lead to tremors influence on trade-offs and distortion, which will substantially reduce the net growth. In the sense that infrastructure investment policies that are not on target will distort economic sustainability and economic development. Third, With various considerations of the city structure and economic effects, the government adopted a policy to create access to the Pandaan-Malang toll road. In opening the access, it will pass through four gates (exit toll), namely the exit toll in Lawang, Pakis, Karanglo (Singosari), and Cemorokandang (Malang City).

\section{METHOD}

The method used in this research is to use the quantitative description method and use the logit test. The logit model is a non-linear regression model that produces an equation where the dependent variable is categorical. The most basic categories of the model produce binary values such as numbers 0 and 1 . The resulting numbers represent a specific category that results from calculating the probability of occurrence of that category. Gujarati (2003) explains that using the logit model is often used in classification data. This test uses the Stata test with primary data that is processed as many as 200 respondents who come from four Malang - Pandaan exit toll areas. The model of this research is:

$$
L_{i}=\ln \left(\frac{P_{i}}{1-P_{i}}\right)=Z_{i}=\beta_{1}+\beta_{2} X_{1}+\beta_{3} X_{2}+\beta_{4} X_{3}+\beta_{5} X_{4}+\beta_{6} X_{5}+e_{i}
$$

Notes:

$\mathrm{L}_{\mathrm{i}}=\log$ of the odds ratio $(0,1)$

$\beta_{1}, \beta_{1}, \beta_{1}, \beta_{1}, \beta_{1}=$ Intercept

$\mathrm{X}_{1}, \mathrm{X}_{2}, \mathrm{X}_{3}, \mathrm{X}_{4}=$ Land Rent, Income, Consumption, Employment, Education $\mathrm{e}_{\mathrm{i}}-$ error term

\section{RESULTS AND DISCUSSION}

Based on the results of the logit test that has been calculated previously, from the three existing variables, namely variables L (land rent), Y (income), C (consumption), W (employment), and L (education), only variable $\mathrm{Y}$ and $\mathrm{C}$ which is significant towards the Malang-Pandaan toll road 
construction. The significance level of the five variables has a $50 \%$ effect on the structure of the Malang-Pandaan toll road. The detailed estimation is provided in Table 2.

Table 2. Logit Test Result

\begin{tabular}{cc}
\hline Variable & $\mathbf{P}>|\mathbf{z}|$ \\
\hline $\mathrm{L}$ & 0.594 \\
$\mathrm{Y}$ & 0.052 \\
$\mathrm{C}$ & 0.095 \\
$\mathrm{~W}$ & 0.894 \\
$\mathrm{E}$ & 0.778 \\
\hline
\end{tabular}

Prob $>$ chi2 $=0.0001$, Pseudo R2 $=0.5079$

Before constructing the Pandaan-Malang exit-toll infrastructure, which was divided into four areas, namely the Pakisaji, Lawang, Singosari, and Cemorokandang areas, the condition of the land or land in these four areas was inhabited as residences by the surrounding communities. And not infrequently the house is also used as the main foundation of the community in meeting the level of expenditure and get the level of income every month. After the construction of toll roads in the four regions, the result was that there were no significant developments or changes in the communities around them. The first, land rent, land prices owned by surrounding communities in the four toll road development zones tend to stagnate without change. Both in terms of quantity and price. Houses or land around the four toll zones affected by evictions carried out by the government to build the toll infrastructure for the purchase of houses that are already inhabited by communities or land that is still vacant on behalf of private owners is given a standard price by the government. Also, there is no special compensation from the government for the construction of toll roads in the four Regions. Thus, some consistent communities remain around the toll road infrastructure development.

For the results of community productivity data that are around the toll road development area, the result is the productivity of the people around the toll road construction persists in the productivity of the trade and manufacturing sectors. For the agricultural sector, it is rarely the main livelihood of the surrounding community because in their local environment many require services in the manufacturing and trade sectors only. Since the construction of the toll road, their productivity in manufacturing and trade has not been a significant change. For the manufacturing sector, those in the toll road construction zone continue to do their work in the manufacturing sector. It implies that there is no change causes their productivity levels to decrease. Whereas for people who have livelihoods in the trade sector, some people have decreased and some people have increased in terms of sales turnover. The decline in sales productivity is in the Lawang and Singosari areas, where many vehicles should pass through their trading business area with a smooth condition and many consumers stop in shops, stalls, or street vendors. Since the construction of the toll road has caused traffic to become jammed, because of traffic jams, many consumers of motorists prefer to remain in the vehicle rather than simply pull over to buy something around the Singosari and Lawang crossing areas. Not a few people who have shop businesses, stalls, and street vendors (street vendors) have decreased turnover so that the productivity of trade communities around the area has decreased. While the increase in sales productivity occurred at the exit toll area in Pakis and Cemorokandang.

The level of income they have received so far has had a positive effect after the construction of the toll road. Previously, the average income level was far from the Regional Minimum Wage, 
which was in the range of Rp. 800,000 - Rp. 1,500,000 per month. After the existence of toll road construction infrastructure, the level of income of the people around the four Regions on average changed but not so significant that it rose in the range of Rp. 1,000,000 - Rp. 1,950,000. his result is in line with research conducted by Hooper et al. (2018) which states that there is a causal relationship between infrastructure development investment and income inequality obtained by the community. There are some Regions that experienced a decrease in the level of income occurred in the Lawang and Singosari exit-toll areas. As discussed earlier, there are aspects of decreasing the level of productivity since the existence of the toll road project, especially in the two Regions. Many vehicles pass through their trading business area with a smooth condition and many consumers stop at shops, stalls, or street vendors. Since the construction of the toll road has caused traffic to become jammed that makes many consumers of motorists prefer to remain in the vehicle rather than simply pull over to buy something around the Singosari and Lawang crossing areas. Therefore, this has an impact on the income they receive each month.

By looking at these conditions, the level of expenditure in terms of consumption also changes but is almost not significant. With the level of income increase that is not so significant, then their level of expenditure in terms of consumption, especially for daily basic needs tends to be fixed. If measured expenditure needs in terms of consumption they should have increased because not a few basic needs for everyday prices have risen (Zezza et al., 2017). With a relatively stable income level, they are required to adjust their expenditure levels to be relatively fixed. To meet their basic daily needs, the community have to downsize, especially for the secondary expenditure level. Their income tends to run out to finance the level of consumption of basic family needs compared to consumption investment. From the available data, consumption in the form of vehicles and electronic devices such as television that they have on average is owned by credit facilities.

Nothing in the community background around the construction of toll road infrastructure has changed either in terms of education or employment. Communities affected by the eviction for toll road construction have the same educational background (Ayuni \& Sariffuddin, 2019). This means that there are no changes before and after the development project. On average parents continue to send their children and even their siblings as best they can, in the sense that they will provide the highest possible education to their children or their siblings assuming their income is sufficient to provide Education facilities up to the bachelor's degree. Data obtained from the field is that the average community residing in the toll road construction area only takes education up to junior high school level. With an educational background that is solely up to junior high school, it has indeed become a reference for compulsory education from the government, namely compulsory education for nine years. However, on the other hand, this condition means that the average economic condition of them is in the middle to lower classes. Which also has an impact on how they think about the education of their children. From the four Regions, many families provide education facilities to their children by relying on scholarships that they obtain. There are even some children who are undergoing schooling in tertiary institutions, both public and private, who are forced to stop drop out because they are unable to pay for their tuition. Seeing these conditions, it cannot be denied that the existence of the toll road construction project did not have a positive impact on their education (Hooper et al., 2018).

\section{CONCLUSION}

The construction of the Malang-Pandaan access toll road infrastructure which is divided into four Regions, namely Singosari, Lawang, Pakis, and Cemorokandang has had several impacts on the welfare of the surrounding community. The first is to increase the level of income and 
consumption of local people. This increase occurs insignificantly means that it cannot be maximally by the expectations of the surrounding community. Secondly, the impact of the opening of the Malang-Pandaan toll road access has not been able to influence the high value of assets such as land, employment, and education level. This indicates that public infrastructure development policies, especially toll road access, have not been able to provide economic sustainability as expected by the government. These results are consistent with what was said by the World Bank where when the government issued a policy on infrastructure investment development must be effective and efficient. This means that infrastructure investment policies that are not on target will cause distortions between economic sustainability and economic growth.

\section{ACKNOLEDGEMENTS}

This work was supported by PNBP research grant of Universitas Negeri Malang Under Contract No: 019492-PN-PNBP-00-2019

\section{REFERENCES}

Annala, C. N., Batina, R. G., \& Feehan, J. P. (2008). Emperical impact of public infrastructure on the Japanese economy. Japanese Economic Review, 59(4), 419-437. https://doi.org/10.1111/j.1468-5876.2008.00427.x

Ayuni, S. I., \& Sariffuddin, S. (2019). Local-Dis-Connection: The Influence of Semarang-Solo Toll Road to Socio-Spatial Disintegration. E3S Web of Conferences, 125(201 9). https://doi.org/10.1051/e3sconf/201912508002

Bom, P. R. D., \& Ligthart, J. E. (2014). Public infrastructure investment, output dynamics, and balanced budget fiscal rules. Journal of Economic Dynamics and Control, 40, 334-354. https://doi.org/10.1016/j.jedc.2014.01.018

Chandra, A., \& Thompson, E. (2000). Does public infrastructure affect economic activity? Evidence from the rural interstate highway system. Regional Science and Urban Economics, 30(4), 457-490. https://doi.org/10.1016/S0166-0462(00)00040-5

Cigu, E., Agheorghiesei, D. T., Gavriluţ ă, A. F., \& Toader, E. (2018). Transport infrastructure development, public performance and long-run economic growth: A case study for the Eu-28 Countries. Sustainability (Switzerland), 11(1). https://doi.org/10.3390/su11010067

Esfahani, H. S., \& Ramírez, M. T. (2003). Institutions, infrastructure, and economic growth. Journal of Development Economics, 70(2), 443-477. https://doi.org/10.1016/S03043878(02)00105-0

Gujarati, D. (2003). Ekonometri Dasar. Jakarta: Erlangga.

Hooper, E., Peters, S., \& Pintus, P. (2018). The causal effect of infrastructure investments on income inequality: Evidence from US States. AMSE Working Papers.

Kyriacou, A. P. (2016). Individualism-collectivism, governance and economic development. European Journal of Political Economy, 42, 91-104. https://doi.org/10.1016/j.ejpoleco.2015.11.005

Ng, C. P., Law, T. H., Jakarni, F. M., \& Kulanthayan, S. (2019). Road infrastructure development and economic growth. IOP Conference Series: Materials Science and Engineering, 512(1). https://doi.org/10.1088/1757-899X/512/1/012045

Nugraha, A. T., Prayitno, G., Situmorang, M. E., \& Nasution, A. (2020). The role of infrastructure in economic growth and income inequality in Indonesia. Economics and Sociology, 13(1), 102-115. https://doi.org/10.14254/2071-789X.2020/13-1/7

O, O.-M. (2015). Infrastructure Development and Economic Growth Nexus in Nigeria. International Journal of Academic Research in Business and Social Sciences, 5(1). https://doi.org/10.6007/ijarbss/v5-i1/1439

Perkins, P., Fedderke, J., \& Luiz, J. (2005). An analysis of economic infrastructure investment in South Africa. South African Journal of Economics, 73(2), 211-228. 
https://doi.org/10.1111/j.1813-6982.2005.00014.x

Rahmawati, F., Ananda, F. P., \& Narmaditya, B. S. (2020). Socio-economic indicators and income inequality: Lesson from West Java in Indonesia. Scientific Papers of the University of Pardubice, Series D, Faculty of Economics \& Administration, 23(3).

Sahnoun, M., \& Abdennadher, C. (2019). Causality between inflation, economic growth and unemployment in North African Countries. Economic Alternatives, 25(1), 77-92.

Seprillina, L., Qurrata, V. A., Narmaditya, B. S., \& Hussain, N. E. B. (2019). The effectiveness productive waqf as a social welfare development through community empowering: A case in Islamic Hospital Foundation Malang. Review of Integrative Business and Economics Research, $9(3), 67-74$.

Sutikno, S., \& Wahyudi, S. M. (2017). The Impact of industrialization on the regional economic development and community welfare. Signifikan-Jurnal Ilmu Ekonomi, 6(2).

The World Bank. (2019). Indonesia Economic Prospects (IEP). https://www.worldbank.org/en/country/indonesia/publication/indonesia-economicprospect

Wulandari, D., Narmaditya, B. S., Prayitno, P. H., \& Ishak, S. (2019). Infrastructure enhancement and households' economic activities: Lesson from Indonesia. Research in World Economy, 10(3), 315-319. https://doi.org/10.5430/RWE.V10N3P315

Ye, C., Zhu, J., Li, S., Yang, S., \& Chen, M. (2019). Assessment and analysis of regional economic collaborative development within an urban agglomeration: Yangtze River Delta as a case study. Habitat International, 83(October), 20-29. https://doi.org/10.1016/j.habitatint.2018.10.010

Zezza, A., Carletto, C., Fiedler, J. L., Gennari, P., \& Jolliffe, D. (2017). Food counts. Measuring food consumption and expenditures in household consumption and expenditure surveys (HCES). Introduction to the special issue. Food Policy, 72, 1-6. https://doi.org/10.1016/j.foodpol.2017.08.007 